\title{
The Opinions of Primary School Teachers Regarding to the Use of Museums in Science Courses
}

\author{
Nil Duban \\ Correspondence: Nil Duban, Faculty of Education, Afyon Kocatepe University, Afyonkarahisar, Turkey.
}

Received: December 12, 2018

Accepted: January 2, 2019 Online Published: January 8, 2019

doi:10.11114/jets.v7i2.3842

URL: https://doi.org/10.11114/jets.v7i2.3842

\begin{abstract}
Museums provide the opportunity to handle real objects, solve problems, and interact with others. And also they are perfect places to ask our own questions, and try to discover the answer. So in many courses, teachers use museums as a learning environment for teaching the subject matter. The purpose of this research is to determine the opinions of primary school teachers about using museums in science courses. In the current research, the qualitative research method and semi-structured interview technique was used. Participants of the study were identified through intense case sampling. The participants of this research were primary school teachers who enrolled in the master program of The Graduate School of Afyon Kocatepe University. The data were collected through audio-taped semi-structured interviews. A semi-structured interview schedule was developed by the researcher. The credibility of this study was enhanced by expert review. The semi-structured interview schedule was sent to experts for review. The trustworthiness of this study was established by the formula proposed by Miles and Huberman. The data of this research are analyzing through content analysis technique. Findings were supported with direct quotes of participants' opinions.
\end{abstract}

Keywords: museums, science courses, teachers, science education

\section{Introduction}

The most comprehensive definition of the museum was made by the International Council of Museums, ICOM, reflecting the contemporary concept of museology. ICOM (2006) defined the museum as follows: "Museum is an institution which is in the service of society and the development of it, open to public, aims to work on tangible or intangible evidence and (a) belongs to people or the environment around them, gathers (b) people to educate them and (c) entertain them. It is also a sustainable non-profit institution that protects, researches and displays these by communicating with the society." In short, museums are places where all kinds of objects that belong to the history of civilization are exhibited under scientific rules, that enriches the public's taste and cultural accumulation, and they are places where the historical data of the researchers are facilitated, developed, and passed on to future generations (ICOM, 2017). Considering these definitions, collections exhibited in museums contribute to the development of students' critical thinking skills about the past and history discipline enabling them to see how the past is interpreted (Marcus, 2007).

ICOM has set the ethical principles and minimum standards required for museums to exhibit their goals and functions in an effective way as follows: Museums help objects that represent humanity's natural and cultural heritage and have scientific, historical, aesthetic and spiritual significance to be understood and valued by society; contains resources and collections that will benefit the society and help them to develop; involves the primary evidence required to produce information; works closely with the communities that the objects in museums belong to; and has a professional working style that is appropriate to legal procedures (ICOM, 2006).

Research about the role of the museums on education has revealed that learning is not limited to books or schools, that museums are places appropriate for individuals to be educated in effective, emotional and cognitive aspects (Cetin, 2006). In today's contemporary museum approach; Through slogans like "Look carefully at the pieces on display, ask questions, discuss them, listen, use your imagination, conduct ideas!" museums become more than just a space and rather a fun learning environment without walls (San, 2008). In this context, museum education is an active, lively, participatory and innovative process, which is established between the museum's collections and the visitor's interest (Greenhill, 1992).

Especially after the 2000s, museums went on to organizing spaces intended for the interests and needs of school groups, 
using technology to support their exhibitions with auditory-visual tools, and offering programs that provide researching and distant learning by using the internet (Gurbuz, 2017). Because the fact that learning in museums is direct and that the objects in museums are stimulating and visually impressive, they provide students with different experiences and contribute to their creativity and provide a more permanent learning (Gartenhaus, 2000).

Nowadays, museum education is perceived as a whole of a wide range of activities, including exhibitions, workshops, and publications, as well as taking students to the museum. In addition, museum education is not only limited to students but has also added families and adults to their structure (Cildir, 2007). According to Hein; the Constructivist theory that emphasizes learning, not teaching, acknowledges that museum visitors actively learn and create personal information. In this context, Hein emphasizes that visitors come to the museum, not for education but to gain experience (Onur, 2012). Looking at this aspect, a wide range of stakeholders are involved in museum education. Talboys (2006) refers to the shareholders that provide educational activities as museum staff, museum educators, groups of students receiving education, teachers, families, and researchers. Museum education includes an interactive museum experience of these parties. For this reason, the inclusion of families who constitute an important part of this group of stakeholders in museum education will contribute to the process to be more beneficial.

With the virtual museum, students and teachers can easily see any museum in a panoramic way without thinking about the cost, time and transportation problems. It can be stated that virtual museums play a facilitating role in the educational sense considering the target achievements of other classes, especially in Social Studies (Aktas, 2017).

The belief that only the disciplines from social fields such as Social Studies, History and Citizenship can benefit from museum education has been drawn away from, and it was found that museums should be benefited from in other classes too. One of the classes recommended to be benefited from museum education is the Science class. Because the use of museum education in many subjects (force and motion, light and sound technologies from past to present, world and universe, etc.) in the scope of science class will contribute to the students' learning process. For example, Natural History and Geology Museums, Science Museums, Planetariums, Industrial Museums, Military Museums, Open Air Museums are some of the museums that can be used directly in relation to the subjects included in the science classes. Research shows that using science museums in science classes and museum-based applications increase students' motivation to learn science-related subjects (Gibson, 1998; Bartels, 2001; Holmes, 2011; Eurydice, 2011). The role of museums in science education is to contribute informal education methodologies to build learning and understanding in science, address all citizens and all learners, and engage them directly and actively in science-oriented experiences and facilitate a direct relationship between the scientific/research community and citizens (Galli, 2014). However, with visits made to the museum, participants of the event may be interested in both science and popular scientific concepts and scientific methods (Stocklmayer, Rennie \& Gilbert, 2010).

Museums possess materials and information that can and should be used in enriching and improving the school curriculum in various disciplines. What is important is for the educational planners to work closely with museum experts on how the educational resources that are available in the museum can be integrated into the curriculum and the learning process at all levels (Arinze, 1999). In this context, it was emphasized in curriculums that Turkey should also benefit from education environments outside of school in starting from primary school. In the curriculum of the Science Course (MoNE, 2013), in-class and out-of-school learning environments are designed within the framework of research-inquiry based learning approach in order to make students learn meaningfully and permanently. In this context, it is once again emphasized in the renewed science program (MoNE, 2017) that science, art, and archeology museums should be used as an informal learning environment. In reference to the Ministry of National Education's (MoNE) emphasis on the fact that museums should be benefited from in science classes as well as other disciplines, it is important that teachers that work in elementary schools reflect museum education to science classes. In this study, the opinions of teachers on the use of museums in science classes were tried to be determined. For this purpose, answers to the following questions were searched:

- What do the teachers think about using museums in classes? For which courses?

- What do the teachers think about using museums in science classes?

- What are the benefits of using museums in science courses?

- What kind of museums do teachers prefer in science classes? Why?

\section{Method}

\subsection{The Research Model}

In this research, phenomenological design (phenomenology) was used in the scope of qualitative research methods. Basic questions to be answered in this pattern; the perception/experience of this phenomenon and the environment and conditions in which this experience occurs (Cresswell, 2015). In this study, the fact that the experiences of teachers who 
use museum education in science classes in and out of school, and the importance and benefit of museums in science classes are being researched, has brought up the need for phenomenological patterns.

Phenomenological research method requires each participant to focus on his/her own world and to describe (with their own words) their experiences (current or past). The primary data collection method used by the researcher is an in-depth interview with open-ended questions (Christensen, Johnson \& Turner, 2015). In this study, the interview technique was used within the scope of phenomenological patterns, in order to get the opinions of teachers on the use of museums in the science classes.

\subsection{Working Group (Participants)}

The study group of the study consisted of the students enrolled in Afyon Kocatepe University Institute of Social Sciences, Elementary School Teacher Training Master Program. The intense case sampling (intense case sampling/intensity sampling) was preferred as a sampling method according to the choices of the participants. The intense case sampling includes an information-loaded status that shows the phenomenon of interest in an intense way (not excessive). The best or richest examples of the phenomenon of interest are investigated. Thus, people with extensive experience or opinions on the subject of research are selected in the study group (Schreiber \& Asner-Self, 2011; Patton, 2014). The master's students who took the course "Modern Approaches in Science and Technology Teaching" conducted by the researcher were chosen as the participants of the study. Teachers in this study group had the chance to visit the museum as a classroom teacher with their own students and also to expand and deepen their experiences in the field of museums with the researches and discussion environments they took. Thus, in consideration of the research subject, the ones that had an intense experience and idea were selected according to the sampling type. Seven class teachers, two of whom were female and five male, were accepted as participants of the study. The seniority of the participants varies between four and eleven years. In this way, the fact that they have at least taught one class in each grade from the four years of the elementary level contributes to the research in terms of their experience. Participants of the study are teachers in the city center, the district center, and the village. Two of the participants work in a private school and five of them work in a public school.

\subsection{Data Collection Tool}

The interviews used in qualitative research were semi-structured. Questions to be asked are included in the interview guide. Questions to be asked to the participant in the guideline are prepared in a semi-structured form and include probe questions (Merriam, 2009). In this study, the semi-structured interview guide developed by the researcher was used as a data collection tool. The semi-structured interview guide used in this study consisted of six open-ended questions based on the literature survey and the experience of the researcher.

\subsection{Internal Validity of the Research}

Within the scope of internal validity or credibility, expert review or expert revision is one of the strategies used. Surely a good expert review should cover the examination of the raw data reviewed by another expert and should contain how reasonable and logical the findings are (Merriam, 2013). In this study, with the use of the interview guide prepared by researchers, a pilot interview was made with a teacher outside of the participants. Then, this recording was put down on paper (it has been transcripts). A control check has been asked from the three experts, by reviewing the transcriptions of the asked questions whether it is clear and understandable, and looking if it covers the subject discussed and thinking out the possibility of it providing the required information. At the end of this study, the validity of the question items was determined; thus, the final form of the interview guide was given. After this operation was conducted, interviews with the participants were done. The recordings made during the interviews were resolved and the transcripts of them were put inside a word file by the researcher. Transcripts and audio recordings were given to a specialist from the field, and the control of their wrong or missing parts were done.

\subsection{The Reliability of the Research}

In qualitative researches, reliability refers to the stability of multiple encoders' responses to the data set. Regarding the reliability, it is possible to use the inter-encoder consensus based on the use of multiple encoders to analyze the transcribed data (Creswell, 2015). Interview coding keys and interview transcripts were read separately by the researcher and an expert, and the necessary arrangements were made to the topics with an "agreement" and "disagreement". For the reliability calculation of the study, the reliability formula proposed by Miles and Huberman (1994) was used. As a result, the reliability of the research was calculated at $92 \%$. The fact that reliability calculations exceeded 70\% is considered reliable for a research (Miles and Huberman, 1994). The result obtained here is considered reliable for research.

\subsection{Data Analysis}

The data obtained in the study were evaluated by the qualitative data analysis. Qualitative data analysis; includes 
encoding the data, separating the text into small units (expressions, sentences or paragraphs), assigning tags to each unit and grouping the codes under themes. A code label can be created from the words of the participants, from statements made by the researchers or can be obtained from the concepts used in social sciences (Creswell \& Plano Clark, 2014). In this research, the answers of each participant were examined in small paragraphs and labeled by writing codes next to each paragraph. After all this tagging operation is complete, which categories the codes issued will use is determined. The obtained categories were grouped in such a way to form a meaningful whole and sub-themes were formed. Thus, sub-themes and categories to be included under the main theme were prepared and shown on the table, and then each of them was explained in detail as the findings of the research. For the transmissibility of the study, the research findings obtained as a result were supported with direct quotations from the participants ' statements. As direct quotations were given by the participants, code names for each participant (Ömer Teacher, Harun Teacher, etc.) were used.

\section{Results}

As a result of the analyses made in this research aiming to determine the opinions of the teachers on the use of museums in science classes. Table 1 presents the themes, sub-themes, and categories.

Table 1. Sub-themes and categories under the main theme of the use of museums in science classes

\begin{tabular}{|c|c|c|}
\hline Main theme & Sub-themes & Categories \\
\hline \multirow{7}{*}{$\begin{array}{l}\text { The use of } \\
\text { museums in science } \\
\text { courses }\end{array}$} & The benefits of museums in science & Cognitive perspective \\
\hline & classes & Affective perspective \\
\hline & Benefiting from museums in classes & Benefiting from museums in other disciplines \\
\hline & \multirow{4}{*}{$\begin{array}{l}\text { Different types of benefiting from } \\
\text { museums in science classes }\end{array}$} & Benefiting from museums in science classes \\
\hline & & Museum trips \\
\hline & & The use of virtual museums \\
\hline & & The use of science centers \\
\hline
\end{tabular}

Under the theme of the benefits of museums in science classes its categories in terms of the child's cognitive and affective perspective; the categories of benefiting from museums in other disciplines and benefiting from museums in science classes under the sub-theme of benefiting from museums in classes; museum trips under the sub-theme of different types of benefiting from museums in science classes; the categories of benefiting from virtual museums and the use of science centres have emerged.

\subsection{The Benefits of Museums in Science Class}

Under the sub-theme of the benefits of museums in the science course, categories of it in cognitive and affective terms have emerged. Subcategories of these categories are shown in Table 2.

Table 2. Categories and subcategories under the sub-theme of benefits of museums in science courses

\begin{tabular}{|c|c|c|}
\hline Sub-themes & Categories & Subcategories \\
\hline \multirow{5}{*}{$\begin{array}{l}\text { Benefits of museums } \\
\text { in science courses }\end{array}$} & & Contribution to learning by doing-living \\
\hline & Cognitive aspects & Providing the permanence of knowledge \\
\hline & & Gaining Science Literacy \\
\hline & Affective aspects & $\begin{array}{l}\text { Increased interest and motivation about science } \\
\text { course }\end{array}$ \\
\hline & & $\begin{array}{l}\text { Making their attitude towards science course } \\
\text { positive }\end{array}$ \\
\hline
\end{tabular}

\subsubsection{Cognitive Benefits}

As a result of the analyses made, the benefit of museums in cognitive and affective aspects in science class has come to light. It is believed that the use of museums in science classes will contribute their learning by doing-living in a cognitive aspect, that it will provide the permanency of the knowledge learned and give students science literacy. Examples of the opinions of the participants can be given as follows:

\section{Contribution to learning by doing-living}

Teachers who think that the use of museums in science classes will contribute to students' learning by doing-living, is expressed as follows: 
Museums can be interesting to students, they can use their sense organs more actively, by interacting with the materials thereby doin-living, by touching them if necessary, and can benefit from them more efficiently through activities. (Teacher Omer)

As a learning method, I think that students will be able to learn more efficiently by doing-living because it involves an active participation since it is an out-of-school learning environment.. (Teacher Harun)

Providing the permanence of knowledge

Teacher Burak, who believes that the use of museums in science classes will ensure the permanence of the knowledge learned, explained his point-of-view like this:

" Regardless of how much we talk about a subject in class and do various activities when the kids see something in the museum about the subject even for five minutes, it makes them not forget it maybe for all their lives. It will create a situation for him/her to use that information for the rest of his/her life, allow him/her to benefit from it."

Gaining Science Literacy

Teacher Umit who believes that the use of museums in science classes will be effective to them to be individuals who read-write about science, states his opinion about the topic as follows:

In science education, it is better for students to go to the museum with an out-of-school activity, to see something, to see the experiments or to see the relevant materials. These make the children embody the concepts and learn them better. Their experiences in the museum increase the student's interest in scientific concepts and their relationship with daily life. By this way, we can raise more science literate individuals. "

\subsubsection{Affective Benefits}

Participants believe that the use of museums in science classes will increase the interest and motivations of students in the course and will make their attitudes towards science lessons more positive. Examples of the participants' opinions on this topic are:

\section{Increased interest and motivation about science course}

Teacher Ayçin who believes that the use of museums in science classes will increase the students' interest in the lesson explains her opinion as follows:

"Trips made to museums help children see the information they have learned in science lessons as concrete. Through what they see as concrete, the student's interest in science classes increases. Thus through museum education, children's motivation for science courses can increase."

\section{Making their attitude towards science course positive}

Teacher Vildan who thinks that museum education can contribute the students to develop a positive attitude toward science course expresses herself in these words: "Children are bored from constantly receiving theoretical information. Children see more concrete things by museum trips. Museum education gains importance to increase the students' attitude towards course (in order for them to love the course and feel happy in science), thanks to its out-of-school environment since it is not just a school-based theoretical knowledge."

\subsection{The Use of Museums in Classes}

Under the sub-theme of the benefiting from museums in classes, categories of in other disciplines and science courses have emerged. Categories of this subtheme are shown in Table 3.

Table 3. Categories under the benefits of museums in courses sub-theme

\begin{tabular}{cl}
\hline \multicolumn{1}{c}{ Sub-theme } & \multicolumn{1}{c}{ Categories } \\
\hline & Benefiting from museums in science courses \\
Benefiting from museums in classes & Benefiting from museums in other disciplines
\end{tabular}

As a result of the analyses made, classes that stand out about benefiting from museums are especially fields that belong to the sub-disciplines of social studies. The result that scientific fields benefit very minimally from museums is obtained. Examples of the opinions of participants about these topics are as follows:

\subsubsection{Benefiting From museums in Science Courses}

Participants have expressed that in science classes, museum education was benefited from very minimally. Teacher Selcuk who stated that the benefit from museums is very minimal in science classes has stated his opinion in these words: 
"I think that there are a lot of museums that are devoted for social fields like history museums, ethnography museums, and archeology museums. I believe that museums about science are maybe at the third or fourth place. I have made some research about this and saw that there are very few science museums in our country. There are also very few articles on the science-museum relationship and very few studies about them. However, there are hundreds of studies abroad, it is not as advanced as theirs in our country yet. The reason for this may be that there are very few science museums.

\subsubsection{Benefiting From Museums in Other Disciplines}

Teacher Burak, one of the participants who thought that the most important lessons in using museums are social studies, history and life lessons, expressed himself in these words:

"Because I have never visited a museum about science before when I think about museums I always remember social studies. When we were in elementary school, our teacher always made a trip to the museum each year, when it came to history. That's why social studies and history comes to my mind at first."

In a similar way, teacher Vildan also states "In social studies lessons, museums can be used in historical subjects, and the monuments there are associated with those topics." that she mainly benefited from museum education in the fields of social sciences.

\subsection{The Ways to Benefit From Museums in Science Classes}

In accordance with the opinions of the participants, it was revealed that museum education can be used in different ways in science classes. The main points expressed by the participants are that the science courses could be carried out by making museum trips, benefiting from virtual museums and using science centres. Subcategories of these categories are shown in Table 4.

Table 4. Categories under different types of benefiting from museums in science classes sub-theme

\begin{tabular}{ll}
\hline \multicolumn{1}{c}{ Sub-theme } & Categories \\
\hline & Making museum trips \\
Different types of benefiting from museums in science & Using virtual museums \\
classes & Using science centres \\
\hline
\end{tabular}

\subsubsection{Making Museum Trips}

Teacher Ömer, one of the participants who believe that classes can be taught more efficiently by making trips to the museum, expresses his opinion on the subject as follows: "Let me tell you something that comes to my mind about science education. Let us say we are going to have a class or make an experiment about historical animal remains. We can do this in the museum. When we take them to a museum that has such remains, we can provide a better, more interesting environment for children as they will be acquainted with the data first-hand. Thus, he/she can understand science much better.

And teacher Vildan can give on the learning outcomes of the lesson by showing them through museums. If we're going to open this up a bit more, for example, if it is a biology-related issue in science education, it can be benefited, for example the living things and life lessons in the $3^{\text {rd }}$ and $4^{\text {th }}$ grades... by visiting the natural history museum, they can get information about the living creatures of the past and maybe even see their fossils. For example, there is a museum like this in our capital Ankara. Those who live in that city or in cities nearby can benefit from this museum for science class about a lesson they have learned." He has given examples for effective uses of museums in science classes.

\subsubsection{Using Virtual Museums}

Teacher Burak who states that virtual museums can be benefited from in classes, explains his personal experience as follows:

"Virtual museums, I myself sometimes use them out of personal interest. Because of my interest in history, I visit the virtual museum of Bursa Ulucami in 3D and learn about it. Although children do not see the objects one-on-one or personally touch/feel them, to be able to see it even if it is virtual, is important for them to live it. I think that the topics that are handled through virtual museums can be more useful than just telling them theoretically."

Teacher Umit talked about virtual museums based on a study he came across that was made in China, and explained the advantages of virtual museums as follows:

"A digital science museum, I think that is very advantageous. It is very difficult for a teacher to plan a museum trip and provide financial opportunities. The virtual museum is advantageous in terms of saving time and saving from the trouble of taking and bringing back the students. The teacher can open the interactive virtual museum right away and show them experiments from there instantly." 
Teacher Ömer expressed the importance of the living place with these words: "I work at a primary school in a town. There aren't any museums in this town. So when I need to benefit from museums in my courses, I make a search about virtual museums. If I can find virtual museum about the topic of the course, I use it in my class."

\subsubsection{Using Science Centres}

Participants who took science centres within the scope of museums have stated that science centres should be benefited from in science classes in addition to museums. About this topic teacher, Harun expresses his opinion about museums as follows: "We come across events or experimental things more in science centres. The children have the opportunity to have an activity or the chance to participate in one. But we do not see many active events or things done then and there, we just have the opportunity to go and see something that has been done before, see the original state of it and watch events that were lived in the past. At least in our country."

Teacher Burak also expressed that science centres will be very effective in providing the children with concrete subjects and in learning by doing-living: "it seems to me that science centres are playing a much more active role in science. Because in science centres, I think it is more than the materials we can use in the science sciences when it becomes a science center. For example, if I had been a science center where I live, I would have liked to take the children to a science center after each unit, make an experiment there even if it is a very small one, and see it there. Because no matter how much we talk about the topics, seen it there for 5 minutes will allow the children to not forget it maybe all their life. It may be something that will make it possible for him/her to use that information throughout his life and to benefit from it. But since there are no science centres where I live, we try to benefit from a laboratory, materials like a microscope and so on."

\section{Discussion}

It is concluded that class teachers participated in this study believed that benefiting from museums in science courses provides both cognitive and affective benefits. Presenting learning opportunities by doing and living, providing science literacy and contributions to developing a positive attitude towards the course are the points highlighted by teachers.

In this research, in line with the views of the teacher, it is concluded that museums, which are non-school learning environment, provides opportunities that contributed to the learning by doing and living. The students were exposed to passive constraints in the classroom environment by Bitgood (1992) pointed out this issue however, he stated that museums of science provide to the learner possibility of free movement and learning through different stations thanks to his multiple stimulators. Wunar and Kowrach (2015) also stated that in their study, informal learning institutions such as museums and science centers play an important role in promoting science for all learners.

As a result of this study, it was found out that the teachers believed that the use of museums and science centers in science courses positively affected students' attitudes towards and curiosity for science. Similarly, it was also concluded that science centers increased their curiosity for students and contributed to the development of positive attitudes in doing study by Jarvis and Pell (2002) and Lucas (1999).

In this study, it is concluded that teachers who participated in the study thought that museums are useful in developing science literacy. When the literature is examined, the primary purpose of museums in science education is to contribute to science literacy (Medved \& Oatley, 2000; Ramey-Gassey, 1997; Tenenbaum, Rappolt-Schlichtmann \& Zanger, 2004).

In the study, it was concluded that museums were used in many disciplines in the direction of teachers' opinions, but the use of museums is more common in the courses that address social areas (such as life science, social studies, history), and that museums are used less in science courses.

While benefiting from museums in science lessons, it is concluded that a museum trip can be made by taking the students to the museum, but if there is no museum in the living place (village, town, etc.), virtual museums can be used as an alternative.

In this research, it was found that using science centers as active as well together with the use of museum trips and virtual trips would also be be beneficial. In this context, it has been concluded that science centers are effective in the concretization of science subjects of children and participation in activities of children and thus providing opportunities for learning by doing-experiencing. Similar to this conclusion, many studies (Fields, 2009; Foster \& Shiel-Rolle, 2011) revealed that science centers provide positive contribution to gaining science literacy by presenting a learning experience by doing and experiencing.

In the research, it was revealed that the teachers thought that planning the museum trip in science courses was difficult to provide transportation and financial possibilities. In many studies (Ata, 2002; Gulec \& Alkis, 2003; Bozdogan \& Yalcin, 2009; Senturk 2015), it was concluded that the financial inadequacies, permission procedure and the shortcomings in planning the trip prevented the museum trips to be carried out at the wanted level. The results obtained from all these studies showed that have been parallel with each other. 
In the light of the results of the study, it is thought that it would be beneficial to encourage teachers for prevent the use of museums at low levels in science courses. For this, it can be said that the procedure to be necessary for museum trips should be facilitated and the financial possibilities should be improved. Especially, in order for students living in rural areas to benefit from museums, virtual museum applications need to be expanded. Thus, even if the visit of the museum is not done personally, it will be possible for students to benefit from museums thanks to virtual trips. Science centers offer students great opportunities for science lessons and contribute to their learning by doing-experiencing. For this, the widespread influence should be increased by the number of science centers across the country should be increased. In current research qualitative method was used, it is suggested that quantitative researches can be carry out with a big sample.

\section{References}

Aktas, V. (2017). The attitudes of the teachers of social studies about the use of virtual museum, (Unpublished master's thesis). Marmara Üniversity, İstanbul, Turkey.

Arinze, E. N. (1999). The Role of the Museum in Society, Guyana Workshop, Public Lecture: Museums, Peace, Democracy and Governance in the $21^{\text {st }}$ Century.

Ata, B. (2002). Teaching history with museums and historical places: The views of history teachers on 'museum education' (Unpublished doctoral thesis). Gazi Üniversity, Ankara, Turkey.

Bartels, D. M. (2001, September 19). On-site science: Why museums, zoos and other informal classrooms need to be a bigger part of the reform equation. Education Week, 21, 45.

Bitgood, S. (1992). The anatomy of an exhibit. Visitor Behavior, 7(4), 4-15.

Bozdogan A. E., \& Yalcin, N. (2009). The educational aimed using levels of Science and technology museums in Ankara. Journal of National Education (Milli Eğitim Dergisi), 182; 232-248.

Cetin, Y. (2006). An evaluation devoted to improvement of conscious about conservation of natural and cultural wealth in course contents of bachelor's degree of education faculties primary school teaching department. Journal of Fine Arts Institute, 12, 43-50.

Christensen, L. B., Johnson, R. K., \& Turner, L. A. (2015). Research methods, design and analysis. (Aypay, A. Translation Ed.). Ankara: Anı Publishing.

Cildir, Z. (2007). Adult education with teachers 'Feza Gürsey science center precedent' (Unpublished master's thesis). AnkaraUniversity, Ankara, Turkey.

Creswell, J. W. (2015). Mixed research methods-qualitative and quantitative research design according five approaches. (M. Bütün; S. B. Demir, Translation Ed.). Ankara: Siyasal Publishing.

Creswell, J. W., \& Plano Clark, V. L. (2014). Designing and conducting mixed methods research. (A. Delice, Translation Ed.). Ankara: Anı Publishing.

Eurydice (2011). Science education in Europe: National policies, practices and research. Education, Audiovisual and Culture Executive Agency. Eurydice Turkey Unit. http://eacea.ec.europa.eu/education/eurydice

Fields, D. (2009). What do students gain from a week at science camp? Youth perceptions and the design of an immersive, research-oriented astronomy camp. International Journal of Science Education, 31(2), 151-171. https://doi.org/10.1080/09500690701648291

Foster, J. S., \& Shiel-Rolle, N. (2011). Building scientific literacy through summer science camps: A strategy for design, implementation and assessment. Science Education International, 22(2), 85-98.

Galli, F. (2014). The Role of Museums in Science Education: Arguments from the Field and from the Case of the National Museum of Science ands Technology Leonardo da Vinci. Science, Innovation and Society Conference, CNR Rome, 19-21 November 2014.

Gartenhaus, A. R. (2000). Creative Thinking and Museums (Translation: R. Mergenci ve B. Onur), (B. Onur Ed.). Ankara Üniversity Children Culture and Application Center Publishing, No:7, Ankara.

Gibson, H. L. (1998, April). Case studies of an inquiry-based science program's impact on students' attitude towards science and interest in science careers. Retrieved December 2, 2011, from http://www.eric.ed.gov/PDFS/ED417980.pdf

Greenhill, H. E. (1992). Working in Museum and Gallery Education. University of Leicester, Department of Museum Studies.

Gulec, S., \& Alkis, S. (2003). The communicative dimension of museum trips in social studies teaching. Journal of Uludağ Üniversity Education Faculty, 17(1), 63-78. 
Gurbuz, E. (2017). Examination of classroom teachers' views on museum education according to various variables (Unpublished master's thesis). Necmettin Erbakan Üniversity, Konya, Turkey.

Holmes, J. A. (2011). Informal learning: Student achievement and motivation in science through museum-based learning. Learning Environ Res., 14: 263-277. https://doi.org/10.1007/s10984-011-9094-y

ICOM. (2006). Code of ethics for museums, http://www.icom.museum. html, (22.12.2015)

ICOM. (2017). International Council of Museums webpage. http://icomturkey.org/tr/müzeler

Jarvis, T., \& Pell, A. (2002). Effect of the challenger experience on elementary children's attitudes to science. Journal of Research in Science Teaching, 39(10), 979-1000. https://doi.org/10.1002/tea.10055

Lucas, K. B. (1999). When Mr. Jones took grade 5 to the science center. The Australian Association for Research in Education and the New Zealand Association for Research in Education. Melbourne.

Marcus, A. S. (2007). Representing the past and reflecting the present: museums, memorials, and the secondary history classroom, Social Studies, 98(3)3, 105-110. https://doi.org/10.3200/TSSS.98.3.105-110

Medved, M. I., \& Oatley, K. (2000). Memories and scientific literacy: remembering exhibits from a science centre. International Journal of Science Education, 22(10), 1117-1132. https://doi.org/10.1080/095006900429475

Merriam, S. (2009). Qualitative research, A guide to design and implementation. $3^{\text {rd }}$ Edition. San Francisco, CA: Jossey-Bass.

Merriam, S. B. (2013). Qualitative research:A guide to design and implementation (S. Turan, Translation Ed.). Ankara: Nobel Publishing.

Miles, M. B., \& Huberman, A. M. (1994). Qualitative data analysis: an expanded sourcebook. ( ${ }^{\text {nd }}$ Edition). Calif.: SAGE Publications.

MoNE (2013). Science Curriculum. (For Primary and Secondary classes, $3^{\text {rd }}, 4^{\text {th }}, 5^{\text {th }}, 6^{\text {th }}$, $7^{\text {th }}$ and $8^{\text {th }}$ ). Ankara: Goverment Press.

MoNE (2017). Science Curriculum. (For Primary and Secondary classes, $3^{\text {rd }}, 4^{\text {th }}, 5^{\text {th }}, 6^{\text {th }}$, $7^{\text {th }}$ and $8^{\text {th }}$ ). http://mufredat.meb.gov.tr/ProgramDetay.aspx?PID=143. Date accessed: 12 November 2017.

Onur, B. (2012), Modern Museum, Education and Development. Ankara: Imge Publishing.

Patton, M. Q. (2014). Qualitative research and evaluation methods. $1^{\text {st }}$ Ed. (M. Bütün; S. B. Demir, Translation Ed.). Ankara: Pegem Publishing.

Ramey-Gasser, L. (1997). Learning science beyond the classroom. The Elementary School Journal, 97(4), 433-450. https://doi.org/10.1086/461875

San, I., (2008). Education and Museum Seminar (18-21 October 2007) Ankara: Kök Publishing.

Schreiber, J. B., \& Asner-Self, K. (2011). Educational research. The interrelationship of questions, sampling, design, and analysis. NJ: John Wiley \& Sons, Inc.

Senturk, E. (2015). Field trips to science centers: Teachers' perspectives, roles, and reflections (Unpublished master's thesis). Middle East Technical University, Ankara, Turkey.

Stocklmayer, S., Rennie, L., \& Gilbert, J. (2010). The roles of the formal and informal sectors in the provision of effective science education. Studies in Science Education, 46(1), 1-44. https://doi.org/10.1080/03057260903562284

Talboys, K., G. (2006). Museum educator's handbook. ( $2^{\text {nd }}$ Ed.). England: Ashgate Publishing.

Tenenbaum, H., Rappolt-Schlichtmann, G., \& Zanger, V. (2004). Children's learning about water in a museum and in the classroom. Early Childhood Research Quarterly, 19, 40-58. https://doi.org/10.1016/j.ecresq.2004.01.008

Wunar, B., \& Kowrach, N. (2015). Redefining the role of museums in science education, Paper presented at the International Conference New Perspective in Science Education, $4^{\text {th }}$ Ed.

\section{Copyrights}

Copyright for this article is retained by the author(s), with first publication rights granted to the journal.

This is an open-access article distributed under the terms and conditions of the Creative Commons Attribution license which permits unrestricted use, distribution, and reproduction in any medium, provided the original work is properly cited. 